\title{
Mass Balance of C, Nutrients, and Mineralization of Nitrogen during Anaerobic Co-Digestion of Rice Straw with Cow Manure
}

\author{
Furqan Muhayodin ${ }^{1,2, *}$, Albrecht Fritze ${ }^{1}\left(\mathbb{D}\right.$ and Vera Susanne Rotter ${ }^{1}$ \\ 1 Department of Environmental Technology, Chair of Circular Economy and Recycling Technology, Technische \\ Universität Berlin, 10623 Berlin, Germany; a.fritze@tu-berlin.de (A.F.); vera.rotter@tu-berlin.de (V.S.R.) \\ 2 Department of Farm Machinery and Power, University of Agriculture, Faisalabad 38000, Pakistan \\ * Correspondence: furqan.muhayodin@campus.tu-berlin.de
}

\section{check for} updates

Citation: Muhayodin, F.; Fritze, A.; Rotter, V.S. Mass Balance of C, Nutrients, and Mineralization of Nitrogen during Anaerobic Co-Digestion of Rice Straw with Cow Manure. Sustainability 2021, 13, 11568 https: / / doi.org/10.3390/ su132111568

Academic Editors: Zhihui Bai, Zhanying Zhang, Changsen Zhang and Zhiguang Yang

Received: 31 August 2021

Accepted: 18 October 2021

Published: 20 October 2021

Publisher's Note: MDPI stays neutral with regard to jurisdictional claims in published maps and institutional affiliations.

Copyright: (c) 2021 by the authors. Licensee MDPI, Basel, Switzerland. This article is an open access article distributed under the terms and conditions of the Creative Commons Attribution (CC BY) license (https:// creativecommons.org/licenses/by/ $4.0 /)$.

\begin{abstract}
Anaerobic co-digestion technology (AcoD) can be used to process rice straw (RS) and cow manure (CoM) to produce energy and a digestate rich in nutrients, while the improper disposal of RS and CoM causes environmental problems. The overall effectiveness of the anaerobic digestion technology can be improved by utilizing the nutrients available in the digestate. It is also a way to reduce the usage of mineral fertilizer by recycling the nutrients available in the digestate. The co-digestion of RS with CoM was performed in a newly developed digester (F1) and in a mesophilic digester (F2) used as a reference. The mass balance of $\mathrm{C}$, macronutrients ( $\mathrm{N}, \mathrm{P}, \mathrm{K}, \mathrm{Ca}, \mathrm{Mg}$, and $\mathrm{S}$ ), and their distribution into a liquid digestate (LD) and a solid digestate (SD) was investigated in both digesters. The mass balance was used to evaluate the carbon available in the biogas and in the digestate. It was also used to investigate the recovery potential of the macronutrients after the AD process. Moreover, the assessment of the resulting digestate was carried out to suggest its potential use in agriculture. The amount of $C$ measured in the biogas was the same in both digesters $(41.0 \%$ and $38.0 \%$ of the initial C). Moreover, the conversion efficiency of $\mathrm{C}$ from the substrate into methane was $23.4 \%$ for $\mathrm{F} 1$ and $21.0 \%$ for $\mathrm{F} 2$. The $\mathrm{Ca}, \mathrm{Mg}, \mathrm{K}$, and $\mathrm{P}$ were conserved in the digestate because their recovery rates (RR) were close to $100 \%$. However, a relatively low RR was observed for $\mathrm{N}(84.1 \%$ in $\mathrm{F} 1$ and $86.8 \%$ in F2) and S (87.1\% in F1 and $86.5 \%$ in F2) in both the digesters. After separation $\mathrm{n}$ of the SD, from 79.1 to $83.4 \%$ (in F1) and 75.0 to $82.4 \%$ (in F2) of the final nutrients were available in the LD. The assessment of the SD suggested its use in agriculture not only for soil amendment but also as a K-providing organic fertilizer.
\end{abstract}

Keywords: rice straw; cow manure; anaerobic co-digestion; nutrients; digestate

\section{Introduction}

Anaerobic digestion (AD) is a biological process in which the specific microorganisms transform the biomass into biogas in the absence of oxygen [1]. It also provides a digestate that can substitute for fertilizers [2] as it is rich in nutrients for crops [3]. Many studies have shown that $\mathrm{AD}$ technology can process many types of waste, which also include crop straw and manure $[1,4,5]$. Rice straw (RS) is a crop residue left on the cultivated land after the crop has been harvested [6]. It was reported by the Food and Agriculture Organization of the United Nations that about 830 million tons of RS were generated in 2019 worldwide [7]. The common uses of RS are for heating, cooking, animal feeding, and paper producing, while the rest of the straw is left unused in the fields [6]. In situ incorporation of the RS in the soil and open-field burning are the common practices used by the farmers for its disposal, especially in the parts of the world where there is a short time to make the fields ready for the sowing of the next crop [8]. These practices are not environmentally friendly as they contribute to the enhancement of emissions of greenhouse gas [8,9]. Moreover, plowing back RS into the soil can potentially increase foliar disease and reduce crop yields [10]. 
Various types of manure, such as that of swine, cattle, and chickens, produce another kind of agricultural waste that also contributes to environmental problems. Excessive application of nitrogen $(\mathrm{N})$ and phosphorus $(\mathrm{P})$ to the soil causes the contamination of water bodies. It also contributes to the emission of gases, such as ammonia $\left(\mathrm{NH}_{3}\right)$, nitrous oxide $\left(\mathrm{N}_{2} \mathrm{O}\right)$, and methane $\left(\mathrm{CH}_{4}\right)$ [11].

During $\mathrm{AD}$, the organic carbon $(\mathrm{C})$ of the substrate is transformed into biogas, a mixture of mainly carbon dioxide $\left(\mathrm{CO}_{2}\right)$ and $\mathrm{CH}_{4}$ [12]. The advantages of the estimation of the $\mathrm{C}$ mass balance include the understanding, prediction, and possibly control of the biogas yield in the AD [1]. A biogas plant operator can evaluate the efficiency of the AD process by the mass balance of $C$ and can also adopt the parameters to increase the degradation of the substrate, which results in the overall enhancement of the biogas yield [13].

The $\mathrm{C} / \mathrm{N}$ is very crucial in the AD process, and its optimal value is 20 to 30 [14]. The $\mathrm{C} / \mathrm{N}$ of the substrate also decreases during $\mathrm{AD}$. This may enhance the fertilizer properties of the digestate [12]. Moreover, the lower $\mathrm{C} / \mathrm{N}$ of the digestate is important for its potential use in agriculture as it can be used if its value is less than 25 [15]. Moreover, during AD the organically bound $\mathrm{N}$ in the substrate is mineralized predominately in ammonium $\left(\mathrm{NH}_{4}{ }^{+}\right)$, which is a readily plant-available form of $\mathrm{N}$ [3]. In establishing a mass balance of the nutrients, it is important to know their availability in the digestate [16]. It can also help to assess the other advantages of the AD technology, which include agronomic, environmental, and economic advantages [17]. Moreover, the evaluation of both the primary macronutrients, such as $\mathrm{N}, \mathrm{P}$, and potassium $(\mathrm{K})$, and the secondary macronutrients, such as calcium (Ca), magnesium $(\mathrm{Mg})$, and sulfur $(\mathrm{S})$ is essential for the utilization of the digestate in agricultural lands by partially or completely replacing the fossil-derived mineral fertilizer [17-19]. Therefore, the better usage of the nutrients available in the digestate is a way to improve the overall effectiveness of the AD technology [1].

Massé et al. [17] and Marcato et al. [18] investigated the fate of the N, P, and K. They studied the mass balance and partitioning of these nutrients in two phases, the liquid digestate (LD) and the solid digestate (SD) in the AD of pig manure. Similarly, Li et al. [1] studied the mass balance of the $\mathrm{C}, \mathrm{N}$, and $\mathrm{P}$ using different crop straw (corn, rice, and wheat) and various types of livestock manure in a batch-scale experimental setup. All these studies were conducted at psychrophilic $\left(10-30{ }^{\circ} \mathrm{C}\right)$ or mesophilic $\left(30-40{ }^{\circ} \mathrm{C}\right)$ temperatures. Moreover, they were limited to mono-digestion, whereas in the agricultural biogas plants, the substrates are usually co-digested with two, or even more, suitable co-substrates. Moreover, all the other studies, except one, were conducted in batch or psychrophilic anaerobic sequencing batch reactors (PASBR), while the continuously stirred mode is usually applied in the AD facilities. Moreover, the status of the mineralization of organically bound $\mathrm{N}$ and the assessment of the digestate for its potential use in agriculture have not been included in these studies.

In the above-mentioned studies, no co-digestion of RS with bovine manure (CoM) was performed. Therefore, it is necessary to evaluate the mass balance of $C$ and the nutrients when the RS is co-digested with the CoM to estimate the $C$ availability in the biogas and the nutrient recovery rate (RR) of the AcoD technology, as well as the distribution of the nutrients into LD and SD. Moreover, the extent of the mineralization of the organically bound $\mathrm{N}$ into $\mathrm{NH}_{4}{ }^{+}$and the recycling of the LD during this co-digestion might affect the quality of the resulting digestate.

The RS was co-digested with the CoM in an innovative temperature-phased anaerobic digestion technology (TPAD), called a "loop digester" (F1), and a reference digester (F2) working in conventional mesophilic conditions [20]. The performance, in terms of the specific methane yield, the anaerobic digestion efficiency, and the volumetric methane production rate of F1, was compared with that of F2. The performance was also evaluated as a function of various feedstock $\mathrm{C} / \mathrm{N}$ ratios (26 to 31), and the results suggested that the best $\mathrm{F} 1$ performance was achieved with a higher $\mathrm{C} / \mathrm{N}$ ratio. It is beneficial if the digester can work at a high $\mathrm{C} / \mathrm{N}$ value as that means it requires a less $\mathrm{N}$-rich co-substrate. Moreover, the LD was recycled back to the digester in the study. The LD contains nutrients such as $\mathrm{N}$ 
which help to improve the $\mathrm{C} / \mathrm{N}$ of the substrate in the $\mathrm{AD}$ and reduce the needed amount of $\mathrm{N}$-rich co-substrates. Less dependence on the co-substrates is beneficial as they are not easily available in some places. Moreover, the status of the trace elements and their effect on the methane yield were studied and published [20].

The focus of this study was the fate of the $\mathrm{C}$ and the macronutrients in the anaerobic co-digestion (AcoD) of RS with CoM in both digesters. The following research questions were formulated and faced: (1) How much $\mathrm{C}$ and nutrients were available in the digestate? (2) What was the partitioning of the output macronutrients into LD and SD? In addition, the extent of the mineralization of the organically bound $\mathrm{N}$ and the assessment of the SD for its potential use in agriculture were also investigated in this study.

\section{Materials and Methods}

\subsection{Substrates}

A mixture of RS and CoM was used in this study as a feedstock for the AcoD process. The mixture contained $130 \mathrm{~g}$ of RS and $350 \mathrm{~g}$ of CoM for the experiments used in this study (Table 1). Their collection, size reduction, sample preparation, and duration of usage during the experiment were presented in detail in a recently published study [20]. The analyzed parameters of the substrates are reported in Table 2.

Table 1. The details of the experiment with key activities performed for digester F1 and F2.

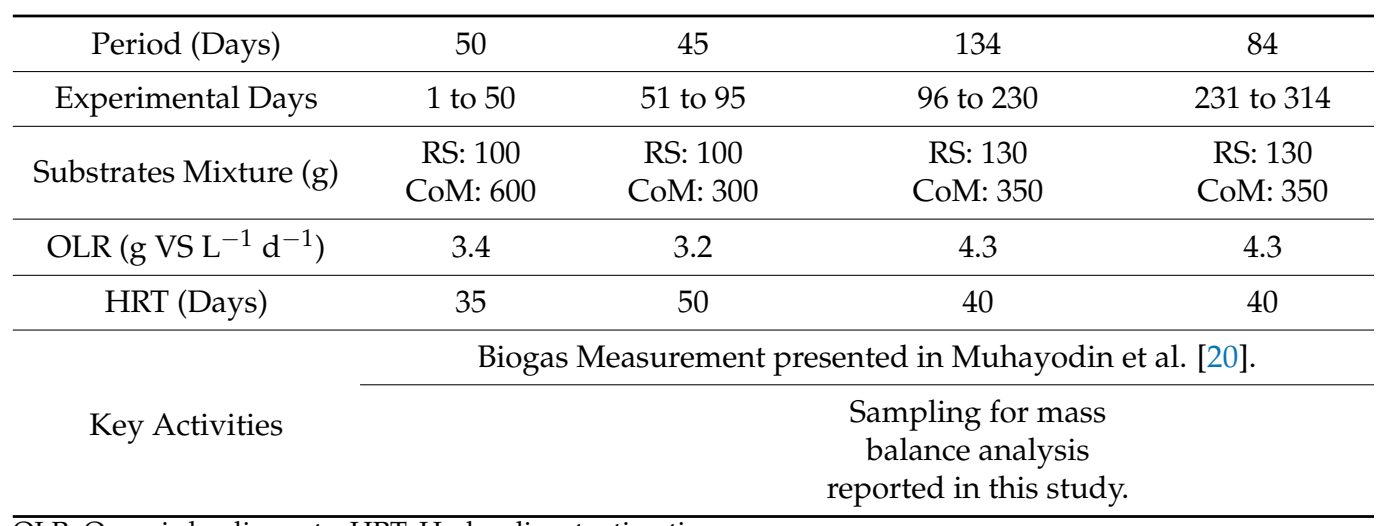

OLR, Organic loading rate; HRT, Hydraulic retention time.

Table 2. Properties of the feeding substrates. The values represent the arithmetic mean (Average) with the range (minimum/maximum) of duplicate or triplicate.

\begin{tabular}{|c|c|c|c|}
\hline Properties & $\begin{array}{c}\text { RS } \\
\text { Average (Mini- } \\
\text { mum/Maximum) }\end{array}$ & $\begin{array}{c}\mathrm{CoM}_{2} \\
\text { Average (Mini- } \\
\text { mum/Maximum) }\end{array}$ & $\begin{array}{c}\mathrm{CoM}_{3} \\
\text { Average (Mini- } \\
\text { mum/Maximum) }\end{array}$ \\
\hline TS (\%) & $89.7(89.6 / 89.8)$ & $7.8(7.8 / 7.9)$ & $8.4(8.1 / 8.6)$ \\
\hline VS (\% of TS) & $84.6(84.6 / 84.6)$ & $78.0(78.0 / 78.0)$ & $75.4(74.9 / 76.0)$ \\
\hline $\mathrm{C}(\%$ of $\mathrm{TS})$ & $40.9(40.9 / 40.9)$ & $40.4(40.4 / 40.4)$ & $40.8(40.6 / 41.1)$ \\
\hline $\mathrm{N}(\%$ of TS) & $0.82(0.82 / 0.83)$ & $1.95(1.93 / 1.97)$ & $2.24(2.22 / 2.27)$ \\
\hline $\mathrm{C} / \mathrm{N}$ & $49.6(49.4 / 49.8)$ & $20.7(20.5 / 20.9)$ & $18.2(17.9 / 18.5)$ \\
\hline $\mathrm{S}(\%$ of TS) & $0.12(0.11 / 0.13)$ & $0.40(0.39 / 0.41)$ & $0.64(0.62 / 0.66)$ \\
\hline $\mathrm{P}(\mathrm{g} / \mathrm{kg} \mathrm{TS})$ & $1.30(1.29 / 1.32)$ & $5.15(5.15 / 5.15)$ & $8.82(8.57 / 9.07)$ \\
\hline $\mathrm{K}(\mathrm{g} / \mathrm{kg} \mathrm{TS})$ & $23.9(23.5 / 24.2)$ & $11.12(10.80 / 11.44)$ & $16.40(16.39 / 16.42)$ \\
\hline $\mathrm{Ca}(\mathrm{g} / \mathrm{kg} \mathrm{TS})$ & $7.26(7.14 / 7.38)$ & $44.0(43.87 / 44.12)$ & $44.3(-/-)$ \\
\hline $\mathrm{Mg}(\mathrm{g} / \mathrm{kg} \mathrm{TS})$ & $2.05(2.03 / 2.08)$ & $23.62(23.54 / 23.69)$ & $19.79(18.64 / 20.95)$ \\
\hline
\end{tabular}

RS, Rice straw; $\mathrm{CoM}_{2,3}$; Cow manure in two different sets; TS, Total solids; VS, Volatile solids. 


\subsection{Digesters and Their Operation}

The first digester, named F1, was newly developed and it consisted of two continuously stirred tank reactors (CSTR). Both of these CSTRs were working in a loop system to complete the AcoD process. The first CSTR was called F1.1; its working volume was $30 \mathrm{~L}$; and it was operated at mesophilic temperature (about $45^{\circ} \mathrm{C}$ ). The second CSTR of F1 was F1.2; its working volume was $4 \mathrm{~L}$; and it was operating at hyper-thermophilic temperature $\left(65\right.$ to $\left.70^{\circ} \mathrm{C}\right)$. The second digester, $\mathrm{F} 2$, was working as a reference at mesophilic temperature $\left(45^{\circ} \mathrm{C}\right)$, and its working volume was $30 \mathrm{~L}$. Regarding the temperatures of both digesters, different ranges of temperature have been reported in the literature for mesophilic conditions. The optimal temperature conditions for acidifying bacteria for mesophilic microorganisms are about 32 to $42{ }^{\circ} \mathrm{C}$ [21].

For the operational purposes, the digester had various ports for the completion of the AcoD process, such as for the collection of biogas, the mechanical agitation of the mixture in the digesters, the temperature control, the feeding of the freshly prepared mixture, and the removal of the substrates after the AcoD. The schematic diagram of the experimental setup with the system boundary is shown in Figure 1.
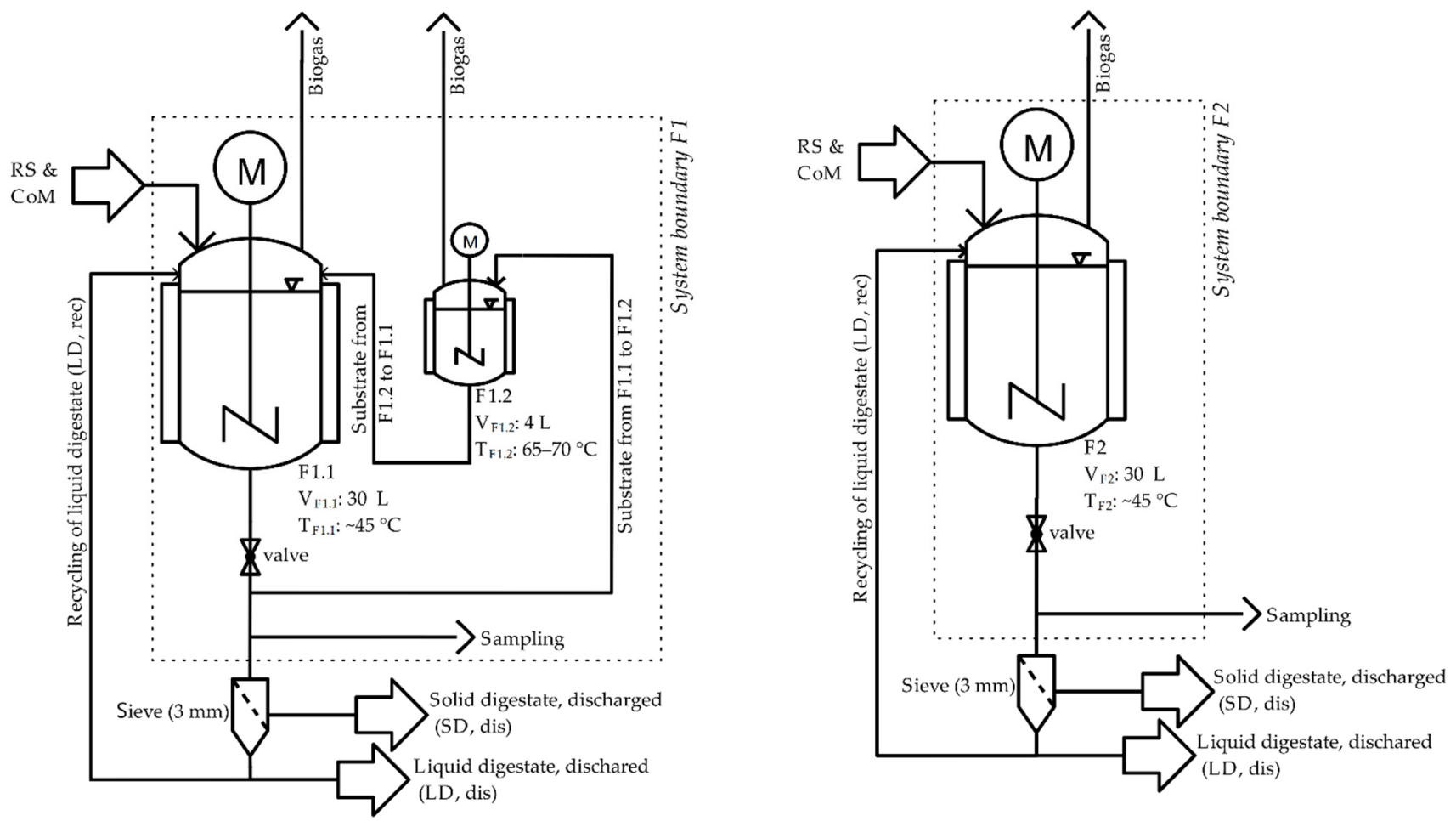

Figure 1. Schematic diagram of both the digesters along with recirculation of obtained liquid digestate and the feeding substrates. The dotted lines show the system boundary in both digesters.

The digesters were working with the AcoD of the same feeding substrates. These digesters had sludge, which was used to continue the AcoD of the RS with the CoM for this study. Therefore, the inoculum was not brought from an external source for starting the $\mathrm{AD}$ process. The digesters were working for more than a year before the experiments used them in this study. The initial inoculum used in the beginning of the process in these digesters was the sludge from the biogas plant in which the maize silage and the CoM were used as substrates.

The AcoD of the RS was performed with the CoM for 314 days in the whole experiment [20]. The first 45 days were considered as being for commissioning and are not reported in Table 1. The feeding of both digesters with the mixture of the input substrates began with a relatively low organic loading rate (OLR) $\left(2.2 \mathrm{~g} \mathrm{VS} \mathrm{L}^{-1} \mathrm{~d}^{-1}\right)$ in commissioning and was successfully increased to $4.3 \mathrm{~g} \mathrm{VS} \mathrm{L}^{-1} \mathrm{~d}^{-1}$. The mass balance of the $\mathrm{C}$ and the 
macronutrients was developed over the period of 134 days. The details of the overall experiment, with the key activities, are presented in Table 1.

Regarding the operation of the digesters, the feeding was carried out every day for the whole week, with a freshly prepared mixture of input substrates. The mixture contained $130 \mathrm{~g}$ of RS and $350 \mathrm{~g}$ of CoM for this study. About 1.0 to $1.1 \mathrm{~L}$ of the substrates were exchanged from F1.1 to F1.2 on a daily basis. The hydraulic retention time (HRT) was 40 days in F1 and F2, while it was 3 to 4 days in F1.2. The digestate was passed through a sieve with a $3 \mathrm{~mm}$ mesh size to obtain the LD. Then, the LD was recirculated to the digesters. The amounts of $\mathrm{LD}$ recycled back to the digester were varied from 500 to $600 \mathrm{~g}$. The purpose of recycling of the LD was to keep the constant total solid content in the digester by diluting the feeding substrates. After the filtration through the sieve, the SD was either used for analysis or disposed of.

\subsection{Sampling Plan}

The samples of the digestates, LD, and SD were taken every week for the first 50 days and bi-weekly for the rest of the experiment (about 80 days) from F1 and F2 for the analysis of the $C$ and the macronutrients. A homogenous sample of about 400 to $500 \mathrm{~g}$ of digestate was taken every time for the analysis. Moreover, about 300 to $400 \mathrm{~g}$ of the digestate was filtered by the sieve to obtain the LD and SD every time for the analysis of the required parameters.

\subsection{Analytical Methods}

The total solids (TS) and volatile solids (VS) of the substrates and all the digestate were measured according to the standards as DIN EN 15934 [22] and DIN EN 15935 [23], respectively.

The measurement of the total $\mathrm{C}$, total $\mathrm{N}$, and total $\mathrm{S}$ was conducted by Elemental Analyzer (Vario EL III, Elementar Analysensysteme GmbH, Langenselbold, Germany). The contents of the nutrients $(\mathrm{Ca}, \mathrm{Mg}, \mathrm{K}$, and $\mathrm{P})$ were analyzed by inductively coupled plasma-optical emission spectroscopy (ICPOES) (iCAP 6000, Thermo Fisher Scientific, Waltham, MA, USA) according to DIN EN 16170 [24]. The samples were prepared using aqua regia digestion in accordance with DIN EN 16174 [25]. All the analyses were carried out in duplicate. The total $C$ and all the nutrients were analyzed in the substrates, digestate, and $\mathrm{LD}$. In the SD, the total $\mathrm{C}, \mathrm{N}$, and $\mathrm{S}$ were also analyzed while $\mathrm{Ca}, \mathrm{Mg}, \mathrm{K}$, and $\mathrm{P}$ were calculated.

Test kits from Macherey Nagel were used to measure the $\mathrm{NH}_{4}{ }^{+}$. The amount of $\mathrm{NO}_{3}{ }^{-}$ is neglected as it comprises a very small percentage, such as 0 to $1.6 \%$, of the total $\mathrm{N}$ after the $\mathrm{AD}[1,3,16]$. The content of the organic nitrogen was calculated using Equation (1).

$$
\mathrm{N}_{\text {org }}=\mathrm{N}_{\text {tot }}-\mathrm{NO}_{3}{ }^{-}-\mathrm{NH}_{4}{ }^{+}
$$

Elster's diaphragm gas meter (BK-G4MT) was used to measure the volume of the biogas. The composition $\left(\mathrm{CH}_{4}, \mathrm{O}_{2}, \mathrm{H}_{2} \mathrm{~S}\right.$, and $\left.\mathrm{CO}_{2}\right)$ of the biogas was determined by using a gas analyzer SEWERIN Multitec ${ }^{\circledR} 545$. The composition of the $\mathrm{CH}_{4}, \mathrm{O}_{2}$, and $\mathrm{CO}_{2}$ was measured in \%, while the $\mathrm{H}_{2} \mathrm{~S}$ was measured in ppm.

\subsection{Calculations for Mass Balance}

The mass balances for the carbon and the nutrients were calculated according to the law of mass conservation. Equation (2) shows the general mass flows balance with the digester input being equal to the digester output plus the mass balance delta $(\triangle M B)$. The delta mass balance term describes the mismatch of the mass balance, also referred to as loss. The $\dot{m}_{i}$ represents the substance flow, as $C$ or the respective nutrient mass flows. The mass flow $\dot{m}_{i_{\text {in }}}$ is the sum of all the input flows of the substance $i$ over the various input substrates, i.e., RS and CoM as displayed in Equation (3). The mass flow $\dot{m}_{i_{\text {out }}}$ is the sum of the output flows of the substance $i$ over the output flows of the discharged solid and liquid 
digestate (SD, dis and $\mathrm{LD}$, dis) as well as the gaseous products $\mathrm{CH}_{4}$ and $\mathrm{CO}_{2}$ in the biogas as presented in Equation (4).

$$
\dot{m}_{i_{\text {in }}}=\dot{m}_{i_{\text {out }}}+\Delta M B
$$

With:

$$
\begin{gathered}
\dot{m}_{i_{\text {in }}}=\sum_{j} \dot{m}_{i_{j}}=\dot{m}_{R S} \times x_{i_{R S}}+\dot{m}_{C o M} \times x_{i_{C o M}} \\
\dot{m}_{i_{\text {out }}}=\sum_{k} \dot{m}_{i_{k}}=\dot{m}_{S D, d i s} \times x_{i_{S D, d i s}}+\dot{m}_{L D, d i s} \times x_{i_{L D, d i s}}+\dot{m}_{B G} \times x_{i_{B G}}
\end{gathered}
$$

The mass of $\mathrm{C}$ in the biogas was calculated using Equation (5). The mass of the biogas was calculated based on its volume flow, composition $\left(\% \mathrm{CH}_{4}\right.$ and $\left.\% \mathrm{CO}_{2}\right)$, which was measured during the experiment daily, and its component densities $\left(\mathrm{CH}_{4} 0.72 \mathrm{~kg} / \mathrm{m}^{3}, \mathrm{CO}_{2}\right.$ $\left.1.96 \mathrm{~kg} / \mathrm{m}^{3}\right)$ [26]. The moisture contained in the biogas was absorbed by silica gel in an airtight container before measuring the biogas composition.

$$
\dot{m}_{\mathrm{C}_{B G}}=\dot{V}_{\mathrm{CH}_{4}} \times \varrho_{\mathrm{CH}_{4}} \times x_{\mathrm{C}_{\mathrm{CH}_{4}}}+\dot{V}_{\mathrm{CO}_{2}} \times \varrho_{\mathrm{CO}_{2}} \times x_{\mathrm{C}_{\mathrm{CO}_{2}}}
$$

A detailed overview of the mass balance calculation can be found in the supplementary material S1.

The mass of the obtained digestate after the AcoD was estimated by deducting the mass of the produced biogas from the fed substrates [26]. This method was proposed by Tampio et al. [26].

The RR is the percentage (\%) of nutrients available in the digestate relative to their initial values (before AcoD) [1]. The RR (\%) is also expressed in Equation (6).

$$
R R[\%]=\frac{\sum_{j} \dot{m}_{i_{k}}}{\sum_{k} \dot{m}_{i_{j}}} \times 100
$$

The inorganic $C$ content was measured in the samples of the input substrates (RS and $\mathrm{CoM}$ ) and also in the unseparated digestate. As expected, in the biological substrates, the fraction of inorganic $C$ to the total $C$ was low for the RS and the digestate, with $1.3 \%$ and $2.2 \%$, respectively. In the CoM alone, the fraction of inorganic $\mathrm{C}$ was about $10.8 \%$ with respect to the total $\mathrm{C}$. However, the inorganic content was neglected, considering the small contribution of the CoM to the total input $\mathrm{C}$, as shown in Figure 2. Consequently, the fraction of inorganic $C$ in the total input $C$ was approximately $2.1 \%$. Hence, the calculations of the $C$ conversion efficiency into methane are based on the total $C$ but assumed to be equal to the organic $C$. 


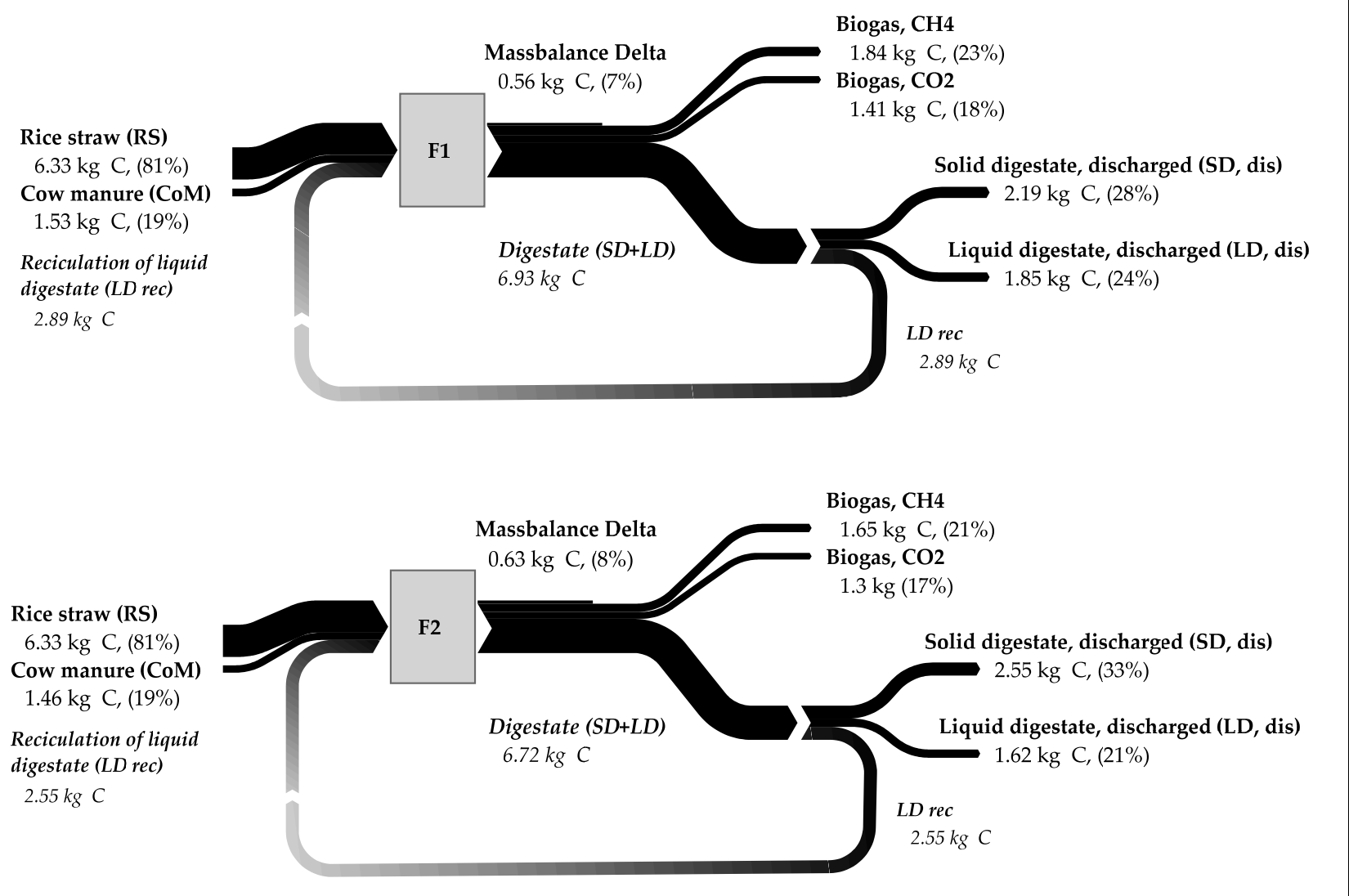

Figure 2. Mass balance of carbon (C) in F1 and F2 for 134 days. The input flows of RS and CoM sum as $100 \%$ and are the basis for the output flows $\mathrm{CH}_{4}, \mathrm{CO}_{2}$ and the discharged SD and LD. LD rec is the process internal flow. Mass balance delta $(\triangle \mathrm{MB})$ represent the $\mathrm{C}$ losses during $\mathrm{AD}$.

\section{Results and Discussion}

\subsection{Properties of Substrates}

Table 2 shows the obtained results of the general properties of the RS and CoM used in this study. The RS contained $89.7 \%$ total solids (TS). The VS were $84.6 \%$ on a dry weight basis of the substrate (expressed as \% of TS). The elemental analysis resulted in $40.9 \% \mathrm{C}$ and $0.8 \% \mathrm{~N}$ contents on a dry weight basis of the RS. The amount of $\mathrm{N}$ was low, and the amount of $\mathrm{C}$ was high, therefore the $\mathrm{C} / \mathrm{N}$ was 49.6 . These properties of the RS were comparable to those reported by other researchers [27]. Additionally, the nutrient contents in the RS were consistent with those reported in other studies [28,29].

A total of four different sets of $\mathrm{CoM}\left(\mathrm{CoM}_{1}, \mathrm{CoM}_{2}, \mathrm{CoM}_{3}\right.$, and $\left.\mathrm{CoM}_{4}\right)$ were used in the overall experiment [20] but only two were used in this part of the study and both were procured from the same farmer, but at different times. $\mathrm{CoM}_{2}$ was used in the first half of the experiment and $\mathrm{CoM}_{3}$ in the second half. The amount of CoM used in this study was $350 \mathrm{~g}$.

The characteristics of $\mathrm{CoM}_{2}$ and $\mathrm{CoM}_{3}$ did not differ appreciably except for a few parameters. Both sets of CoM had almost similar TS, VS, C/N, Ca, and Mg. The contents of $S, P$, and $\mathrm{K}$ were higher in $\mathrm{CoM}_{3}$ than in $\mathrm{CoM}_{2}$. The amount of $\mathrm{C}$ and $\mathrm{N}$ present in the CoM was comparable to the results of another study in which cattle manure was used [1]. The mass fractions of the nutrients $(\mathrm{P}, \mathrm{Ca}, \mathrm{Mg}$, and $\mathrm{K}$ ) present in the CoM were different to those reported in another study [1]. It assumed that the difference in these characteristics was due to the different types of manure, which are strongly affected by the types of food fed to cattle, used in these studies $[30,31]$. 


\subsection{Mass Balance of $C$ in $F 1$ and $F 2$}

The mass balance of $C$ was calculated in the AcoD of the RS and the CoM. The results are presented in Figure 2. In F1, the total amount of added C was $7.86 \mathrm{~kg}$, and $4.04 \mathrm{~kg}$ was still available in the digestate. Therefore, about $52 \%$ of the initial $\mathrm{C}$ was still present in the digestate. Moreover, during the AcoD process, a total of $1.41 \mathrm{~kg} \mathrm{C}-\mathrm{CO}_{2}(18.0 \%$ of the initial $\mathrm{C})$ and $1.84 \mathrm{~kg} \mathrm{C}-\mathrm{CH}_{4}(23.4 \%$ of the initial $\mathrm{C})$ were released as biogas, which represents a share of about $41.0 \%$ of the initial C.

The initial added $C$ was decreased from $7.8 \mathrm{~kg}$ to $4.17 \mathrm{~kg}$ during the AcoD process in F2. This was about a $54.0 \%$ share of the initial C, and $38.0 \%$ was released into the biogas. Compared to F2, the amount of $\mathrm{C}$ released as biogas was only about $3.0 \%$ higher in $\mathrm{F} 1$ relative to its initial amount. Moreover, Zhang et al. [32] studied the distribution of $C$ in the solid, liquid, and biogas in various biogas plants treating a wide range of organic waste. Their results showed different distributions of $C$ into biogas for different waste types, such as 70 to $90 \%$ for food waste, 30 to $50 \%$ for the livestock waste, and 15 to $30 \%$ for night soil sludge. These results also showed that the distribution of $C$ varied significantly with the type of the organic waste. The calculated net loss of C was similar (about $7.0 \%$ in F1 and 8.0\% in F2) in both digesters. Similarly, Gulhane et al. [33] reported a loss of 3.3\% in their study during the $\mathrm{C}$ mass balance analysis in the bio-methanation of vegetable market waste in an anaerobic baffled reactor. The net loss of 4 to $10 \%$ of $C$ is acceptable, and the potential sources of error are sampling, analytical, and also the production of biogas under temperature and pressure conditions which are not normal [1]. This amount of loss might be high in the case of farm- or industrial-scale biogas plants, but it is expected to have this during the experimentations as reported in the literature [1,33]. The experiments were conducted in the lab-scale digesters. This experimental setup was better to represent the actual environment at the farm-scale biogas plants as compared to the batch-scale experiments where a controlled environment exists. Therefore, the results obtained in this study are more realistic. Although, if the amount of digestate had been measured then the accuracy of the experiment might even have improved.

The efficiency of the $\mathrm{C}$ conversion from the substrates into $\mathrm{CH}_{4}$ was $23.4 \%$ for $\mathrm{F} 1$ and $21.0 \%$ for $\mathrm{F} 2$. The $\mathrm{C}$ conversion efficiency was similar in both digesters. The efficiency of the $\mathrm{C}$ conversion into $\mathrm{CH}_{4}$ in this study was higher than those efficiencies found in another study where various substrates were investigated in batch experiments $(11.2 \%$ for RS, $8.2 \%$ for corn straw, $9.5 \%$ for wheat straw, $15.8 \%$ for swine manure, $8.5 \%$ for cattle manure, and $12.8 \%$ for chicken manure). The higher $C$ conversion efficiency in this study could be due to the enhanced hydrolysis at higher temperature conditions. Moreover, similar to $\mathrm{Li}$ et al. [4,5], co-digestion was carried out in this study and proved to enhance the $\mathrm{CH}_{4}$ as compared to that of mono-digestion $[4,5]$.

\subsection{Mass Balance of Nutrients in F1 and F2}

The total amount of $\mathrm{N}$ added by the substrates to F1 and F2 was $208.9 \mathrm{~g}$ and $205.2 \mathrm{~g}$, respectively, as shown in Figure 3. The $\mathrm{N}$ mass balance was calculated, and it showed an RR of $84.1 \%$ and $86.8 \%$ for F1 and F2, respectively (Figure 3). The RR of N was close to that of previously published results where a 93-97\% RR was observed for various types of manure and $85-91 \%$ for different straws in the AD [1]. Moreover, an RR of $82 \%$ of $\mathrm{N}$ was estimated during the co-digestion of cow dairy with additional substrates at a commercial digester [34]. Additionally, a 90-94\% RR of $\mathrm{N}$ was found when establishing a mass balance of full-scale agro-industrial AD plants [13].

Although, total $\mathrm{N}$ is found to be mostly available in the digestate [19]. In this study, $\mathrm{N}$ was not fully conserved in the digestate $(\mathrm{RR}<100 \%)$ in both digesters. The RR of $\mathrm{N}$ obtained in our study was comparable with the results of these studies [1,13,34]. Moreover, Muhayodin et al. [27] used the results of $12 \mathrm{AD}$ experiments with a wide range of substrates, determining an average RR of $\mathrm{N}$ of $92.5 \%$, which is comparable to the results in this study. Ma et al. [34] assumed that the first possible reason for it not being a $100 \% \mathrm{RR}$ of $\mathrm{N}$ during the $\mathrm{AD}$ might be its transformation into biogas in the form of $\mathrm{NH}_{3}$. Schievano et al. [13] 
measured the $\mathrm{N}$ in biogas, and it was approximately $0.3 \%$ to $0.7 \%$ relative to the input $\mathrm{N}$. Möller et al. [19] also reported a low amount of $N(<1 \%)$ in biogas stream. These results indicated that there could be other causes for such a low RR of $\mathrm{N}$ in this study. Further processes that can cause a low RR of $\mathrm{N}$ are the formation of struvite and ammonium carbonate [19]. The RR of $\mathrm{N}$ was not $100 \%$ in this study, and it can be attributed to the partial retention of organic/inorganic matter in the digesters. Schievano et al. [13] also reported these phenomena in their study.

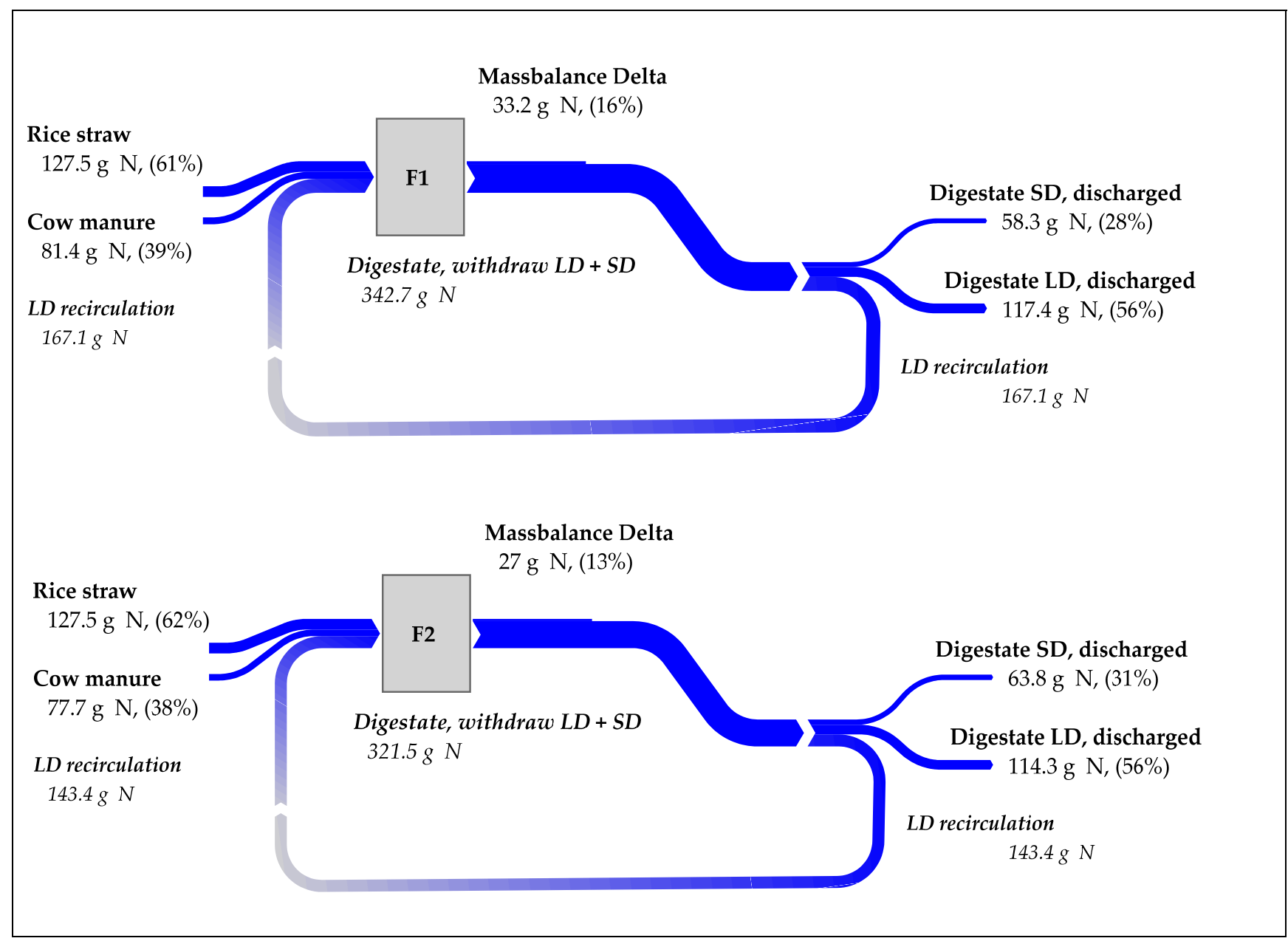

Figure 3. Mass balance of nitrogen (N) for 134 days and its output distribution into LD and SD in F1 and F2. The input flows of RS and CoM sum as 100\% and are the basis for the output flows (discharged SD and LD). LD rec is the process internal flow. Mass balance delta $(\triangle \mathrm{MB})$ represents the losses during $\mathrm{AD}$.

The RR of $\mathrm{N}$ in this study and other studies mentioned above were similar, but Alcántara et al. [16] obtained contradicting results as the total $\mathrm{N}$ available in the digestate was about 8 to $23 \%$ more than before the AD. According to the authors, the possible explanation for the higher RR might be due to the low initial activity of the inoculum used in their experiment. The amount of hydrolyzed microalgae and $\mathrm{N}$ released in the aqueous phase might be overestimated because the $\mathrm{RR}$ of $\mathrm{N}$ was calculated as the difference between the microalgae test and the control test.

The mass balance of $\mathrm{P}$ is also shown in Figure S6 in the supplementary material for F1 and F2. The amount of total P added by the substrates to the F1 and F2 was $46.8 \mathrm{~g}$ and $45.5 \mathrm{~g}$, respectively. The RR of P in F1 and F2 was $96.1 \%$ and $96.5 \%$, respectively. The RR of $\mathrm{P}$ in both digesters was very high as more than $90 \%$ is considered to be a high quantity [19]. Alcántara et al. [16] observed a 99\% RR of P in the AD of microalgae. Another study showed an RR of $\mathrm{P}$ at a high rate (91-97\%) during the AD of various straws and manure 
in batch experiments [1]. Schievano et al. [13] studied the mass balance of P in full-scale AD plants and reported a 91-94\% RR. The RR of P in this study was comparable with the results mentioned in other studies $[1,13,16]$.

Massé et al. [17] investigated the detention of macronutrients in PASBR. The P retention was found to be $25.5 \%$ of the initial P because the process tends to maximize the sedimentation. Moreover, a significantly low RR (64\%) was also observed for P during the AD of pig slurry, probably due to its accumulation in the digester. Crystal lining was found in the digester when it was opened and scanning electron microscopy (SEM-EDS) observation proved the presence of $\mathrm{P}$ in the lining [18]. These two studies resulted in a much lower RR of $\mathrm{P}$, unlike the studies mentioned above and in this study.

Figure S7 in the supplementary material shows the mass balance of K in F1 and F2. A total $\mathrm{K}$ of $422.6 \mathrm{~g}$ in F1 and $420.0 \mathrm{~g}$ in F2 was added in the form of input substrates. The RR of K amounted to $97.1 \%$ for $\mathrm{F} 1$ and $93.4 \%$ for F2. Therefore, it can be concluded that $\mathrm{K}$ was conserved in the digestate in both digesters during the AcoD process as its RR was not far from $100 \%$. Moreover, the RR in both digesters was comparable to another study in which the mass balance of $\mathrm{K}$ was investigated in three full-scale biogas plants showing a net RR of 94 to $98 \%$ [13]. However, in the other two studies with swine manure and pig slurry, there was about a 100\% RR of K during the AD [17,18]. Their findings were also close to the obtained results in this study.

The mass balances of $\mathrm{Ca}, \mathrm{Mg}$, and $\mathrm{S}$ in both digesters are shown in Figures S8-S10, respectively, in the supplementary material. The RR of Ca for F1 and F2 was 100\%. The $\mathrm{RR}$ of $\mathrm{Mg}$ was about $95.1 \%$ in F1 and $93.1 \%$ in F2. There were only two studies found in which the fate of the $\mathrm{Ca}$ and $\mathrm{Mg}$ during the AD was discussed $[17,18]$. The results showed that, on average, $8.7 \%$ of the $\mathrm{Ca}$ and $18.7 \%$ of the $\mathrm{Mg}$ were retained in the bioreactors during the AD of swine manure. However, according to the authors, this retention of the $\mathrm{Ca}$ and $\mathrm{Mg}$ was not statistically significant [17]. Marcato et al. [18] have observed a significant detention of $\mathrm{Ca}(44 \%)$ and $\mathrm{Mg}(32.5 \%)$. These nutrients partially crystallized out as phosphates and carbonates.

The RR of $S$ was about $87.1 \%$ in F1 and $86.5 \%$ in F2. There were only a few reports available regarding the RR of $S$ in biogas plants [19]. The overall mass balance of $S$ showed an RR of about $84 \%$ in a study conducted by Marcato et al. [18] and they attributed it to the presence of $\mathrm{H}_{2} \mathrm{~S}$ in the biogas. Moreover, more than $50 \%$ of the $\mathrm{S}$ was retained in the bioreactors during the AD of swine manure in PASBR [17].

In the AcoD of RS with CoM in both the digesters, $\mathrm{Ca}, \mathrm{Mg}, \mathrm{K}$, and $\mathrm{P}$ were found in the digestate because their recovery rates were not far from $100 \%$. However, a relatively low RR was observed for $\mathrm{N}(84.1 \%$ in F1 and $86.8 \%$ in F2) and $\mathrm{S}(87.1 \%$ in F1 and $86.5 \%$ in F2) in both the digesters. Moreover, the magnitude of the RR of all the nutrients was almost similar in F1 and F2. Therefore, the performance of both digesters in terms of the RR of the nutrients was same. Moreover, the trends of the macronutrients over the whole duration of this experiment in both digesters are presented in Figures S2-S5 (supplementary material) for the sake of general comparison.

On the other hand, F1 performed much better than F2 in terms of specific methane yield, especially at a higher C/N (31) [20]. Working at a higher C/N is always beneficial as it requires a lesser amount of $\mathrm{N}$-rich co-substrates. If $\mathrm{F} 1$ performed better with a low need of N-rich co-substrates and the RR of the nutrients was also high, then its overall performance was higher for the recovery of the energy and nutrients.

\subsection{Partitioning of Output Nutrients into LD and SD}

The digestate was separated into the LD and SD from both digesters. A fraction of the LD was recycled to the digesters while the SD and the remaining LD were discharged. Figure 3 and Figures S6-S10 (supplementary material) represent the amount of available nutrients in the LD and SD. The overall LD represented, on average, about $83 \%$ of the final output digestate. On the nutrient mass balance, the LD from F1 retained about $82.9 \%$ of the total $\mathrm{N}, 83.2 \%$ of $\mathrm{S}, 80.0 \%$ of $\mathrm{P}, 83.4 \%$ of $\mathrm{K}, 79.1 \%$ of $\mathrm{Ca}$, and $82.0 \%$ of $\mathrm{Mg}$, relative to 
the nutrient output. In F2, it retained about $80.2 \%$ of the total $\mathrm{N}, 78.8 \%$ of $\mathrm{S}, 75.0 \%$ of $\mathrm{P}$, $81.3 \%$ of $\mathrm{K}, 76.1 \%$ of $\mathrm{Ca}$, and $82.4 \%$ of $\mathrm{Mg}$, respectively.

A study conducted by Marcato et al. [18] revealed that $85 \%$ of $\mathrm{N}, 90 \%$ of $\mathrm{K}$, and $80 \%$ of S were available in the LD. Tambone et al. [11] studied the distribution of the nutrients available in the digestate into the LD and SD from thirteen full-scale AD plants. They concluded that $87 \%$ of total $\mathrm{N}$ as Total Kjeldahl Nitrogen (TKN) and $71 \%$ of $\mathrm{P}_{2} \mathrm{O}_{5}$ were present in the LD. The amount of $\mathrm{N}, \mathrm{P}, \mathrm{K}$, and $\mathrm{S}$ available in the LD of both digesters was not far from the results of these studies.

Massé et al. [17] studied the distribution of nutrients in the AD of swine manure in PASBR. They found a share of $62 \% \mathrm{~N}, 34 \% \mathrm{P}, 70 \% \mathrm{~K}, 21 \% \mathrm{Ca}$, and $6 \% \mathrm{Mg}$ in the LD. The amount of $\mathrm{N}$ and $\mathrm{K}$ available in the LD was still comparable with the results obtained in this study. The amounts of $\mathrm{Ca}, \mathrm{Mg}$, and $\mathrm{P}$ available in the LD contradict the results of this study. One possible explanation could be the use of separation techniques: sequenced batch reactors were used in their study, which tended to maximize the sedimentation of the nutrients. Moreover, only swine manure was used by Massé et al. [17], instead of the mixture of RS and CoM used in this study. The availability of a higher amount of $\mathrm{Ca}$ and $\mathrm{Mg}$ in swine waste can possibly re-fix the phosphate in the form of chemical precipitates [35]. Similarly, only 1 to $16 \%$ of P existed in the LD during the AD of various types of manure, and the remaining $\mathrm{P}$ was available in the SD due to its precipitation [1].

In the final output digestate, SD represented on average about $17 \%$. In terms of the nutrient output mass balance, it retained $17.0 \%$ and $19.9 \%$ of the total $\mathrm{N}, 16.7 \%$ and $21.2 \%$ of $\mathrm{S}, 20.0 \%$ and $25.0 \%$ of $\mathrm{P}, 16.6 \%$, and $18.7 \%$ of $\mathrm{K}, 20.9 \%$ and $23.9 \%$ of $\mathrm{Ca}$ and $17.9 \%$ and $17.5 \%$ of $\mathrm{Mg}$ in F1 and F2, respectively. These percentages were relative to the final output digestate which consisted of LD recycled, LD discharged, and SD discharged. The amount of $\mathrm{N}$ and $\mathrm{P}$ present in the SD in F1 and F2 was comparable to another study [11]. In contrast, over $80 \%$ of the $\mathrm{P}$ in various manures (over $97 \%$ for swine manure) was available in $\mathrm{SD}$ as a precipitate after the AD [1].

\subsection{Mineralization of Nitrogen in F1 and F2}

The amount of total $\mathrm{N}, \mathrm{NH}_{4}{ }^{+}$and organic nitrogen in the input mixture before and after the AcoD process was estimated in order to assess the extent of the mineralization of $\mathrm{N}$ in the AcoD of RS with CoM in both digesters. The values are presented in Table 3.

Table 3. The values represent the arithmetic mean (Average) with the range (minimum/maximum) of 134 values (experiment days) of the digestate.

\begin{tabular}{|c|c|c|c|c|}
\hline & \multicolumn{2}{|c|}{ F1 } & \multicolumn{2}{|c|}{ F2 } \\
\hline & $\begin{array}{c}\text { Before } \\
\text { AcoD } \\
\text { Average } \\
\text { (Minimum/Maximum) }\end{array}$ & $\begin{array}{c}\text { After } \\
\text { AcoD } \\
\text { Average } \\
\text { (Minimum/Maximum) }\end{array}$ & $\begin{array}{c}\text { Before } \\
\text { AcoD } \\
\text { Average } \\
\text { (Minimum/Maximum) }\end{array}$ & $\begin{array}{c}\text { After } \\
\text { AcoD } \\
\text { Average } \\
\text { (Minimum/Maximum) }\end{array}$ \\
\hline Total N (g/kg FM) & $3.2(2.5 / 3.4)$ & $2.6(2.5 / 2.8)$ & $3.2(3.0 / 3.4)$ & $2.7(2.3 / 2.8)$ \\
\hline $\mathrm{NH}_{4}^{+}(\mathrm{g} / \mathrm{kg} \mathrm{FM})$ & $0.8(0.6 / 1.3)$ & $1.3(1.1 / 1.5)$ & $0.8(0.5 / 1.1)$ & $1.6(1.3 / 1.8)$ \\
\hline Organic N (g/kg FM) & $2.4(1.4 / 2.6)$ & $1.3(1.0 / 1.6)$ & $2.4(2.3 / 2.8)$ & $1.1(0.8 / 1.5)$ \\
\hline
\end{tabular}

FM, Fresh matter; AcoD, Anaerobic co-digestion.

The mass fractions of organic $\mathrm{N}$ and $\mathrm{NH}_{4}{ }^{+}$were similar before the AcoD process in both the digesters. After AcoD, on average, the mass fraction of $\mathrm{NH}_{4}{ }^{+}$was $1.3 \mathrm{~g} / \mathrm{kg}$ of fresh matter (FM) in F1 because it was analyzed in the fresh sample. In F1, it represented about $49 \%$ of the final N. During the AcoD process in F2, the mass fraction of $\mathrm{NH}_{4}{ }^{+}$, on average, was $1.6 \mathrm{~g} / \mathrm{kg}$ FM, which represented about $60 \%$ of the final $\mathrm{N}$. The share of organic nitrogen in the total $\mathrm{N}$ after AcoD was 51\% in $\mathrm{F} 1$ and $40 \%$ in $\mathrm{F} 2$. The $\mathrm{NH}_{4}{ }^{+}$had a good share of total $\mathrm{N}$ in both digestates. This form of the $\mathrm{N}$ is readily available to the plants. 
Grimsby et al. [3] studied the extent of the mineralization of $\mathrm{N}$ in the AD of Jatropha press cake. Their results revealed that about $77 \%$ of the final $\mathrm{N}$ existed as $\mathrm{NH}_{4}{ }^{+}$. Alcántara et al. [16] obtained $51-57 \%$ of the total $\mathrm{N}$ as $\mathrm{NH}_{4}{ }^{+}$after the $\mathrm{AD}$ of microalgae. Schievano et al. [13] found about $55-70 \%$ of the final $\mathrm{N}^{2} \mathrm{NH}_{4}{ }^{+}$after the $\mathrm{AD}$ of various substrates in full-scale plants. The proportion of $\mathrm{NH}_{4}{ }^{+}$to the final $\mathrm{N}$ in F1 $(49 \%)$ and F2 $(60 \%)$ was comparable with the results of these studies.

The mass fraction of $\mathrm{NH}_{4}{ }^{+}$was not analyzed in the $\mathrm{SD}$ in this study. The amount of $\mathrm{NH}_{4}{ }^{+}$could be possibly still significant in the SD from both the digesters due to their high moisture content, which was about $73 \%$. Moreover, Kataki et al. [36] found 12 to $41 \%$ of the final $\mathrm{NH}_{4}{ }^{+}$in the SD due to high moisture (70 to $78 \%$ ) availability. Thus, due to the availability of $\mathrm{NH}_{4}{ }^{+}$, the short-term fertilizer value of the $\mathrm{SD}$ may have increased [13].

Apart from its fertilizer value, $\mathrm{NH}_{4}{ }^{+}$is needed by the methanogenic bacteria in the $\mathrm{AD}$ process. Its consumption takes place during the $\mathrm{AD}$ of fatty acids [37]. The mass fraction of $\mathrm{NH}_{4}{ }^{+}$was lower in $\mathrm{F} 1(1.3 \mathrm{~g} / \mathrm{kg} \mathrm{FM})$ as compared to that in $\mathrm{F} 2(1.6 \mathrm{~g} / \mathrm{kg} \mathrm{FM})$. The concentration of $\mathrm{NH}_{4}{ }^{+}$is also an indicator of process stability. An $\mathrm{NH}_{4}{ }^{+}$concentration above $3.8 \mathrm{~g} / \mathrm{L}$ indicates inhibition of the process. The reduction in methane productivity was started when the $\mathrm{NH}_{4}{ }^{+}$concentration was about $2.0 \mathrm{~g} / \mathrm{L}$, while its production was almost stopped at a concentration level of $5.5 \mathrm{~g} / \mathrm{L}$ in the $\mathrm{AD}$ of the organic fraction of municipal waste [38]. The measured $\mathrm{NH}_{4}{ }^{+}$levels suggest no inhibition for both digesters. In addition, the concentration of $\mathrm{NH}_{4}{ }^{+}$at which the inhibition may start ranges from 1.5 to $10 \mathrm{~g} / \mathrm{L}$, as reported in the literature [21].

\subsection{Agronomic Properties of SD}

The nutrients available in the SD from the F1 and F2 are presented in Table 4. The results were also compared with other similar studies. The TS contents of the SD from both digesters were the same. These values of TS were also comparable with the results of similar studies as they ranged from 22.5 to $30 \%$ [36].

Table 4. Nutrients available in the SD from F1 and F2 and other studies. The values represent the arithmetic mean (Average) with the range (minimum/maximum) of 12 values. The " \pm " stands for standard deviation reported in the literature.

\begin{tabular}{|c|c|c|c|c|c|}
\hline Reference & F1 & F2 & [36] & [36] & [36] \\
\hline Substrate & $\begin{array}{l}\text { RS+CoM } \\
\text { Average } \\
\text { (Minimum/ } \\
\text { Maximum) }\end{array}$ & $\begin{array}{c}\text { RS+CoM } \\
\text { Average } \\
\text { (Minimum/ } \\
\text { Maximum) }\end{array}$ & $\mathrm{CD}_{\mathrm{SD}}$ & $\mathrm{ICD}_{\mathrm{SD}}$ & $\mathrm{RGC}_{\mathrm{SD}}$ \\
\hline TS (\%) & $27.5(23.3 / 29.3)$ & $27.5(25.3 / 28.6)$ & 30 & 22.5 & 23.5 \\
\hline $\mathrm{N}$ (g/kg TS) & $10.2(9.6 / 11.2)$ & $9.8(9.2 / 10.5)$ & $14.8 \pm 1.2$ & $20.9 \pm 3.2$ & $11.1 \pm 1.3$ \\
\hline $\mathrm{S}(\mathrm{g} / \mathrm{kg} \mathrm{TS})$ & $1.8(1.6 / 2.1)$ & $1.9(1.7 / 2.1)$ & $0.1 \pm 0.0$ & $2.62 \pm 0.1$ & $1.2 \pm 0.1$ \\
\hline$P(g / k g$ TS $)$ & $2.7(1.2 / 4.4)$ & $3.2(2.1 / 4.9)$ & $2.2 \pm 0.1$ & $3.8 \pm 0.0$ & $2.2 \pm 0.0$ \\
\hline $\mathrm{K}(\mathrm{g} / \mathrm{kg} \mathrm{TS})$ & $23.1(18.0 / 33.5)$ & $24.6(14.0 / 34.5)$ & $5.1 \pm 0.1$ & $7.1 \pm 0.0$ & $5.7 \pm 0.2$ \\
\hline $\mathrm{Ca}(\mathrm{g} / \mathrm{kg} \mathrm{TS})$ & $20.7(12.2 / 29.3)$ & $19.4(12.2 / 32.4)$ & $2.4 \pm 0.1$ & $8.9 \pm 0.0$ & $7.1 \pm 0.2$ \\
\hline $\mathrm{Mg}(\mathrm{g} / \mathrm{kg} \mathrm{TS})$ & $6.6(3.6 / 9.9)$ & $6.5(3.1 / 9.5)$ & $1.5 \pm 0.0$ & $2.6 \pm 0.0$ & $2.4 \pm 0.0$ \\
\hline $\mathrm{C} / \mathrm{N}$ & $41.3(39.5 / 44.8)$ & $42.1(39.7 / 45.1)$ & 18 & 16 & 40 \\
\hline
\end{tabular}
gram + cow dung; SD, Solid digestate; TS, Total solids.

The total $\mathrm{N}$ available in the SD from both the digesters was similar. The $\mathrm{N}$ content of SD from F1 and F2 was lower than the digestate resulting from the mono-digestion of cow dung and the AcoD of ipomoea carnea with cow dung. These values of $\mathrm{N}$ from both digesters were similar when the RS was co-digested with green gram and cow dung [36]. Moreover, the total $\mathrm{N}$ available in the digestate from the AcoD of livestock waste with 
maize (2.29 g/ $\mathrm{kg} \mathrm{FM)} \mathrm{and} \mathrm{the} \mathrm{AcoD} \mathrm{of} \mathrm{livestock} \mathrm{waste} \mathrm{with} \mathrm{grass-clover} \mathrm{(2.35} \mathrm{g/} \mathrm{kg} \mathrm{FM)}$ was also similar to the SD from F1 (2.8 g/ $\mathrm{kg} \mathrm{FM)} \mathrm{and} \mathrm{F2} \mathrm{(2.7} \mathrm{g/} \mathrm{kg} \mathrm{FM)} \mathrm{[39].}$

Considering the minimum recommended amount of total $\mathrm{N}(>15.0 \mathrm{~g} / \mathrm{kg}$ TS) in the compost as per German standards [40], the SD from both the digesters $(10.2 \mathrm{~g} / \mathrm{kg}$ TS for $\mathrm{F} 1$ and $9.8 \mathrm{~g} / \mathrm{kg}$ TS for F2) did not fulfill this requirement. The minimum recommended total $\mathrm{N}$ for the organic fertilizer is $10 \mathrm{~g} / \mathrm{kg}$ TS, as per the Indian Fertilizer (control) order, 1985 [36]. It may vary for different countries. However, the SD obtained in this study fulfilled the requirements of the Indian Fertilizer order.

The primary macronutrients include N, P, and K; therefore, all of them are equally important [36]. The amount of $\mathrm{P}$ and $\mathrm{K}$ in the SD from F1 and F2 was also found to be similar (Table 4). The mass fraction of $\mathrm{P}$ in both of the SDs was comparable to other similar studies as they reported a range from 2.2 to $3.8 \mathrm{~g} / \mathrm{kg}$ TS in their results [36]. While the mass fraction of $\mathrm{K}$ found in the $\mathrm{SD}$ from F1 and F2 was higher than the previously reported values [36]. The possible reason for these different values could be the higher availability of $\mathrm{K}$ in the substrates used in this study.

Usually, no limit values of $\mathrm{P}$ and $\mathrm{K}$ have been set to assess the fertilizer properties of the digestate [36]. However, as per German standards, compost should have a minimum $\mathrm{P}$ as $\mathrm{P}_{2} \mathrm{O}_{5}$ and $\mathrm{K}$ as $\mathrm{K}_{2} \mathrm{O}$ content of $5.0 \mathrm{~g} / \mathrm{kg}$ TS and $7.5 \mathrm{~g} / \mathrm{kg}$ TS, respectively [40]. Considering these criteria, the mass fractions of $\mathrm{P}$ and $\mathrm{K}$ in the SD of $\mathrm{F} 1$ and $\mathrm{F} 2$ were higher than the minimum required value.

The secondary macronutrients $(\mathrm{Ca}, \mathrm{Mg}, \mathrm{S})$ in the SD from $\mathrm{F} 1$ and $\mathrm{F} 2$ are also presented in Table 4. The contents of these nutrients were similar in the SD of F1 and F2. The relative abundance of these nutrients in both SDs was as follows: $\mathrm{Ca}>\mathrm{Mg}>\mathrm{S}$. Kataki et al. [36] also observed a similar decreasing trend studying the assessment of SD from AcoD with other substrates, such as cow dung, Impomoea carne, and green gram as a potential crop nutrient.

Apart from the macronutrients, the $\mathrm{C} / \mathrm{N}$ is another important property of organic fertilizer as it helps in the regulation of organic matter mineralization in the soil [41]. The $\mathrm{C} / \mathrm{N}$ for plant and manure-based digestate was reported from 12 to 18 [36,42]. In this study, the $\mathrm{C} / \mathrm{N}$ values are based on the total $\mathrm{C}$. Samples of the digestate were also analyzed for the determination of inorganic C. It was only about $2 \%$ of the total C. Therefore, the total C was assumed as organic $C$ for the sake of comparison with the reported literature. Higher values (41.3 for F1 and 42.1 for F2) of the $\mathrm{C} / \mathrm{N}$ were found in the SD (Table 4). However, these values were comparable with another study ( $\mathrm{C} / \mathrm{N}$ reported as 40$)$ in which the $\mathrm{RS}$ was co-digested with cow dung and green gram [36]. Moreover, Pezzola et al. [15] obtained a $\mathrm{C} / \mathrm{N}$ of 39 in the digestate after the AcoD of straw with pig slurry. The higher $\mathrm{C} / \mathrm{N}$ of the $\mathrm{SD}$ in this study may have resulted due to the higher content of $\mathrm{C}$ in the RS. Pre-treatments such as mechanical size reduction may be used before the AD of RS. Such pre-treatments increase the surface area, which facilitates the acid formation and the breaking of the cell wall, making the organic matter more available to the microbes for its better degradation and may help in a lowering the $\mathrm{C} / \mathrm{N}$ of the digestate [10]. The lower $\mathrm{C} / \mathrm{N}$ is important for its potential usage in agriculture because the digestate can be used in agriculture if the $\mathrm{C} / \mathrm{N}<25$ [15]. Moreover, the balanced $\mathrm{C} / \mathrm{N}$ in the digestate is necessary. The excessive amount of degradable organic substrate relative to $\mathrm{N}$ for the microorganisms causes its low mobilization in the microbial biomass and reduces its crop availability, while the excess $\mathrm{N}$ causes losses through nitrate leaching and ammonia volatilization, etc. [43]. Therefore, composting of the SD from both the digesters can be an option as their $\mathrm{C} / \mathrm{N}$ was higher than the optimal value.

The SD could act as a fertilizer or a soil conditioner in agriculture. The organic fraction contained in the digestate can increase the soil's organic matter, and this implies that the digestate has soil-conditioning properties [44]. The fertilizer properties mean the content of nutrients in the digestate and their existing chemical forms [45]. Compost has been considered more for its soil-conditioning properties due to its lower content of nutrients and higher quality of organic matter [46]. On the other hand, digested sludges have been studied for their fertilizer properties due to their high nutrient content (N and $\mathrm{P}$ ) and low 
C/N [47]. In Table 5, a comparison was made between the well-known organic matrices and the SD obtained from both the digesters in this study, in order to check their properties as soil conditioners and fertilizers. Compost and digested sludge were chosen for the comparison. The compost is studied as organic amendments, while the digested sludges contain a higher amount of macronutrients [48]. The comparison revealed that the average content of $\mathrm{N}$ in both SDs was less than those in the compost and digested sludge. The content of $\mathrm{K}_{2} \mathrm{O}$ was higher in both SDs compared to that of the compost and digested sludges. The $\mathrm{P}_{2} \mathrm{O}_{5}$ content of the SD was similar to the compost of $100 \%$ lignocellulosic residue, while lower than other composts and digested sludges.

Table 5. Comparison between SD, composts, and digested sludges. The values represent the arithmetic mean (Average) with the range (minimum/maximum) of 12 values. The " \pm " stands for the standard deviation reported in the literature.

\begin{tabular}{|c|c|c|c|c|}
\hline $\begin{array}{c}\text { Digestate/ } \\
\text { Compost/ } \\
\text { Digested Sludge }\end{array}$ & $\begin{array}{c}\text { TKN } \\
\text { (g/kg TS) }\end{array}$ & $\begin{array}{c}\mathrm{P}_{2} \mathrm{O}_{5} \\
\text { (g/kg TS) }\end{array}$ & $\begin{array}{c}\mathrm{K}_{2} \mathrm{O} \\
(\mathrm{g} / \mathrm{kg} \mathrm{TS})\end{array}$ & References \\
\hline $\mathrm{SD}_{1}$ & $10.2(9.6 / 11.2)^{a}$ & $6.2(2.7 / 10.1)$ & $27.7(21.6 / 40.2)$ & This study \\
\hline $\mathrm{SD}_{2}$ & $9.8(9.2 / 10.5)^{a}$ & $7.3(4.8 / 11.2)$ & $29.5(16.8 / 41.4)$ & This study \\
\hline GC & $12 \pm 1$ & $6 \pm 1$ & $9 \pm 2$ & [48] \\
\hline $\mathrm{MC}_{1}$ & $19 \pm 0$ & $29 \pm 1$ & $21 \pm 2$ & {$[48]$} \\
\hline $\mathrm{MC}_{2}$ & $17 \pm 1$ & $31 \pm 1$ & $16 \pm 1$ & [48] \\
\hline $\mathrm{DS}_{1}$ & $73 \pm 1$ & $52 \pm 1$ & $5 \pm 0$ & [48] \\
\hline $\mathrm{DS}_{2}$ & $55 \pm 0$ & $50 \pm 1$ & $7 \pm 1$ & [48] \\
\hline $\mathrm{DS}_{3}$ & $50 \pm 2$ & $40 \pm 1$ & $4 \pm 0$ & {$[48]$} \\
\hline $\mathrm{DS}_{4}$ & $50 \pm 2$ & $42 \pm 1$ & $6 \pm 0$ & [48] \\
\hline
\end{tabular}

$\mathrm{SD}_{1}$, Solid digestate from F1; $\mathrm{SD}_{2}$, Solid digestate from F2; GC, Green compost (100\% lignocellulosic residue) $\mathrm{MC}_{1}, \mathrm{MC}_{2}$, Mixed compost (lignocellulosic residues and organic fraction of municipal solid waste in a 1:2 ratio); $\mathrm{DS}_{1}, \mathrm{DS}_{2}, \mathrm{DS}_{3}, \mathrm{DS}_{4}$, Anaerobically digested and dried slurries from municipal wastewater; ${ }^{a}$ Measured as total $\mathrm{N}$.

The primary macronutrients and $\mathrm{C} / \mathrm{N}$ available in the $\mathrm{SD}$ from both the digesters were compared with the corresponding recommended values. Moreover, a comparison was made with the composts and digested sludges to assess their soil conditioning or fertilizer properties. After the assessment, the SD should be considered not only for its conditioning but also for its fertilizer properties only in K-required soils.

Heavy metals such as Cadmium, Chromium, Nickel, Lead, and many others may be available in the substrates and end up in the digestate. The applications of digestate with a higher content of heavy metals may induce portioning to the crops. Zhang et al. [32] analyzed the digestate from biogas plants, treating various types of organic waste. They found the heavy metal contents were negligible in the digestate from all the biogas plants. Unfortunately, these heavy metals were not analyzed in the SD in this study. Most probably, the heavy metals would be negligible in the SD because the feeding substrates were RS and CoM. However, it is still recommended to analyze these in future research work.

In addition to its nutritional status and the presence of heavy metals, the application of digestate as a fertilizer is further associated with potential health hazards. The application of digestate can also cause odor and ammonia emission which are also associated with health risks [49]. The potential health risk from the digestate is partly attributed to the feedstock being used in the AD process [50]. Moreover, many other factors, such as the temperature of digestion, the time for the treatment, the $\mathrm{pH}$ value, the amount of fatty acids, the mode of the operation, and the species of bacteria can affect the decay of harmful bacteria in the AD process [50]. The harmful microbes of health concern, such as Salmollena, Klebsiella, and total coliforms were available when the human excreta were co-digested with the food waste [51]. However, studies on the availability of harmful microbes in the digestate from manure and plant-based substrates were not found [36]. The substrates 
used in this study were RS and CoM, and it is most likely that there would be no harmful microbes in the SD. However, microbial analysis of the SD is recommended to check the potential health hazards associated with its application.

\section{Conclusions}

The following conclusions have been drawn concerning the research questions in this study after analyzing the results.

- The results of the $C$ balance revealed the presence of the same amount of $C$ in the digestate after the AcoD process in both the digesters, which indicates similar effects of the processes on the input carbon. Moreover, the $\mathrm{C}$ conversion efficiency from the input substrates into methane was similar.

- The $\mathrm{Ca}, \mathrm{Mg}, \mathrm{K}$, and $\mathrm{P}$ were preserved in the digestate after the AcoD process. However, the amounts of $\mathrm{N}$ and $\mathrm{S}$ were not the same in the digestate when compared to their input by the substrates. It could be due to the presence of $\mathrm{NH}_{3}$ and $\mathrm{H}_{2} \mathrm{~S}$ in the biogas and their retention in the digesters.

- The separation with the sieve of the output digestate resulted in the partitioning of nutrients into LD and SD. The major portion of the output nutrients was available in the LD.

- The extent of the mineralization of nitrogen was similar in both digesters as the proportion of $\mathrm{NH}_{4}{ }^{+}$in the digestate was similar.

- The assessment of the SD obtained from both digesters revealed that it could be considered for its soil conditioning properties as well as for its fertilizer properties as a substitute for the K-needed fertilizers, by comparing its nutrients with well-known digestates. However, analysis to detect the microbes in the SD is recommended to check the potential health hazards associated with its application.

Supplementary Materials: The following are available online at https:/ /www.mdpi.com/article/10 .3390/su132111568/s1, Figure S1: Mass balance of digester F1 and F2, Figure S2: F1-Trends of TS, C, $\mathrm{N}$, and S in SD + LD, SD, and LD, Figure S3: F1-Trends of TS, P, Ca, K, and Mg in SD + LD and LD, Figure S4: F2-Trends of TS, C, N, and S in SD + LD, SD, and LD, Figure S5: F2-Trends of TS, P, Ca, K, and $\mathrm{Mg}$ in SD + LD and LD, Supplementary S1: Mass balance calculations. Figures S6-S10 show the mass balance of $\mathrm{P}, \mathrm{K}, \mathrm{Ca}, \mathrm{Mg}$, and $\mathrm{S}$ in both digesters.

Author Contributions: Conceptualization, F.M.; methodology, F.M.; formal analysis, F.M. and A.F.; resources, V.S.R.; data curation, F.M.; writing—original draft preparation, F.M.; writing-review and editing, A.F. and V.S.R.; visualization, F.M. and A.F.; supervision, V.S.R.; project administration, V.S.R.; funding acquisition, V.S.R. All authors have read and agreed to the published version of the manuscript.

Funding: Furqan Muhayodin is a doctoral student and is funded by the Ministry of Higher Education Commission (HEC), Pakistan (SAP 50020935). This work was funded by the German Federal Ministry of Education and Research (BMBF) under the project "BIORIST"-A joint research project for innovative process technology for biogas production from rice straw (01LY1508A).

Institutional Review Board Statement: Not applicable.

Informed Consent Statement: Not applicable.

Data Availability Statement: Not applicable.

Acknowledgments: The authors extend their thanks and gratitude to Julia Linden for providing the initial critical constructive comments to improve the quality of this paper. The authors would like to thank Birgit Fischer for the analysis of various samples in the laboratory during the study. We acknowledge support from the German Research Foundation and the Open Access Publication Fund of TU Berlin. We acknowledge the critical feedback from the reviewers that helped to enhance the quality of the paper.

Conflicts of Interest: The authors declare no conflict of interest. 


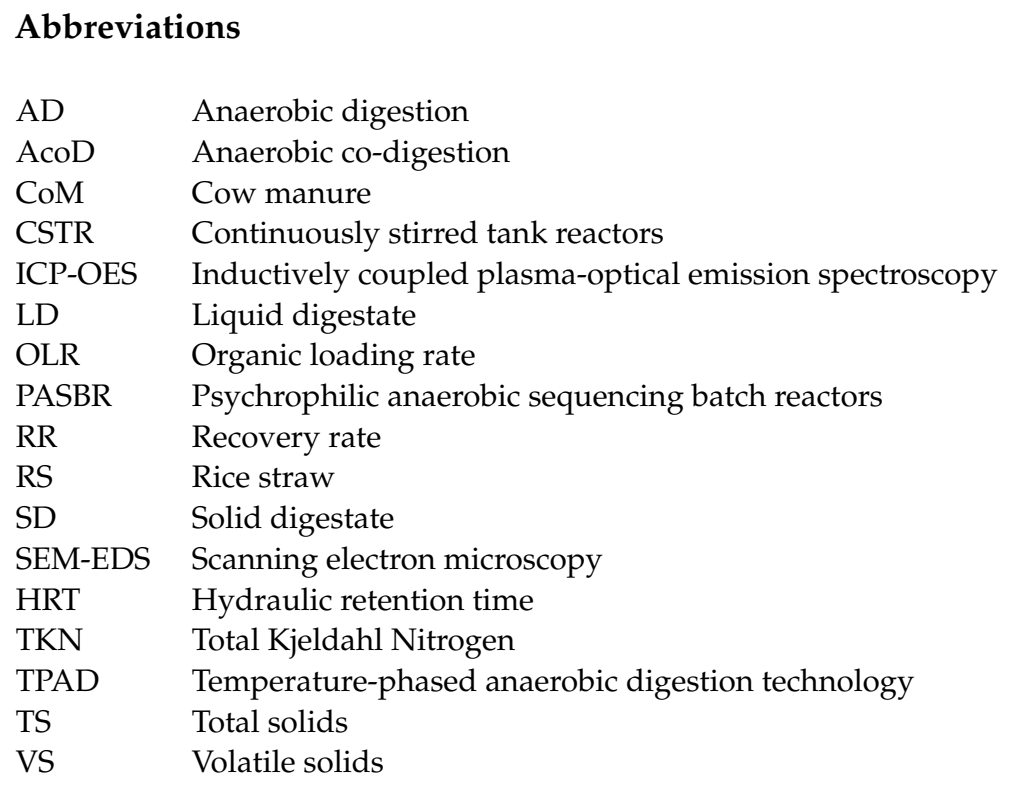

\section{References}

1. Li, H.; Tan, F.; Ke, L.; Xia, D.; Wang, Y.; He, N.; Zheng, Y.; Li, Q. Mass balances and distributions of C, N, and P in the anaerobic digestion of different substrates and relationships between products and substrates. Chem. Eng. J. 2016, 287, 329-336. [CrossRef]

2. Riva, C.; Orzi, V.; Carozzi, M.; Acutis, M.; Boccasile, G.; Lonati, S.; Tambone, F.; D’Imporzano, G.; Adani, F. Short-term experiments in using digestate products as substitutes for mineral $(\mathrm{N})$ fertilizer: Agronomic performance, odours, and ammonia emission impacts. Sci. Total Environ. 2016, 547, 206-214. [CrossRef] [PubMed]

3. Grimsby, L.K.; Fjørtoft, K.; Aune, J.B. Nitrogen mineralization and energy from anaerobic digestion of jatropha press cake. Energy Sustain. Dev. 2013, 17, 35-39. [CrossRef]

4. Li, D.; Liu, S.; Mi, L.; Li, Z.; Yuan, Y.; Yan, Z.; Liu, X. Effects of feedstock ratio and organic loading rate on the anaerobic mesophilic co-digestion of rice straw and cow manure. Bioresour. Technol. 2015, 189, 319-326. [CrossRef] [PubMed]

5. Li, D.; Liu, S.; Mi, L.; Li, Z.; Yuan, Y.; Yan, Z.; Liu, X. Effects of feedstock ratio and organic loading rate on the anaerobic mesophilic co-digestion of rice straw and pig manure. Bioresour. Technol. 2015, 187, 120-127. [CrossRef] [PubMed]

6. Sattar, A.; Arslan, C.; Ji, C.; Sattar, S.; Umair, M.; Sattar, S.; Bakht, M.Z. Quantification of temperature effect on batch production of bio-hydrogen from rice crop wastes in an anaerobic bio reactor. Int. J. Hydrog. Energy 2016, 41, 11050-11061. [CrossRef]

7. FAOSTAT. Global Rice Production by Year. Food and Agriculture of the United Nations. Available online: https://www.fao.org/ faostat/en/\#home (accessed on 15 July 2021).

8. Gadde, B.; Bonnet, S.; Menke, C.; Garivait, S. Air pollutant emissions from rice straw open field burning in India, Thailand and the Philippines. Env. Pollut. 2009, 157, 1554-1558. [CrossRef]

9. Glissmann, K.; Conard, R. Fermentation pattern of methanogenic degradation of rice straw in anoxic paddy soil. FEMS Microbiol. Ecol. 2000, 31, 117-126. [CrossRef] [PubMed]

10. Zhang, R.Z.Z. Biogasification of rice straw with an anaerobic-phased solids digester system. Bioresour. Technol. 1999, 68, 235-245. [CrossRef]

11. Tambone, F.; Orzi, V.; D’Imporzano, G.; Adani, F. Solid and liquid fractionation of digestate: Mass balance, chemical characterization, and agronomic and environmental value. Bioresour. Technol. 2017, 243, 1251-1256. [CrossRef]

12. Raheman, H.; Mondal, S. Biogas production potential of jatropha seed cake. Biomass Bioenergy 2012, 37, 25-30. [CrossRef]

13. Schievano, A.; D’Imporzano, G.; Salati, S.; Adani, F. On-field study of anaerobic digestion full-scale plants (part I): An on-field methodology to determine mass, carbon and nutrients balance. Bioresour. Technol. 2011, 102, 7737-7744. [CrossRef]

14. Li, Y.; Park, S.Y.; Zhu, J. Solid-state anaerobic digestion for methane production from organic waste. Renew. Sustain. Energy Rev. 2011, 15, 821-826. [CrossRef]

15. Pezzolla, D.; Di Maria, F.; Zadra, C.; Massaccesi, L.; Sordi, A.; Gigliotti, G. Optimization of solid-state anaerobic digestion through the percolate recirculation. Biomass Bioenergy 2017, 96, 112-118. [CrossRef]

16. Alcántara, C.; García-Encina, P.A.; Muñoz, R. Evaluation of mass and energy balances in the integrated microalgae growthanaerobic digestion process. Chem. Eng. J. 2013, 221, 238-246. [CrossRef]

17. Masse, D.I.; Croteau, F.; Masse, L. The fate of crop nutrients during digestion of swine manure in psychrophilic anaerobic sequencing batch reactors. Bioresour. Technol. 2007, 98, 2819-2823. [CrossRef] [PubMed]

18. Marcato, C.E.; Pinelli, E.; Pouech, P.; Winterton, P.; Guiresse, M. Particle size and metal distributions in anaerobically digested pig slurry. Bioresour. Technol. 2008, 99, 2340-2348. [CrossRef]

19. Möller, K.; Müller, T. Effects of anaerobic digestion on digestate nutrient availability and crop growth: A review. Eng. Life Sci. 2012, 12, 242-257. [CrossRef] 
20. Muhayodin, F.; Fritze, A.; Larsen, O.C.; Spahr, M.; Rotter, V.S. Co-Digestion of Rice Straw with Cow Manure in an Innovative Temperature Phased Anaerobic Digestion Technology: Performance Evaluation and Trace Elements. Energies 2021, $14,2561$. [CrossRef]

21. Steinhauser, D.D.A. Biogas from Waste and Renewable Resources; WILEY-VCH Verlag GmbH \& Co: Weinheim, Germany, 2011.

22. DIN EN 15934. Sludge, Treated Biowaste, Soil, and Waste-Calculation of Dry Matter Fraction after Determination of Dry Residue or Water Content; ISO: Geneva, Switzerland, 2012.

23. DIN EN 15935. Sludge, Treated Biowaste, Soil, and Waste-Calculation of Loss on Ignition; ISO: Geneva, Switzerland, 2021.

24. DIN EN 16170. Sludge, Treated Biowaste, and Soil-Determination of Elements Using Inductively Coupled Plasma Optical Emission Spectrometry; ISO: Geneva, Switzerland, 2016.

25. DIN EN 16174. Sludge, Treated Biowaste, and Soil-Digestion of Aqua Regia Soluble Fractions of Elements; ISO: Geneva, Switzerland, 2012.

26. Tampio, E.; Marttinen, S.; Rintala, J. Liquid fertilizer products from anaerobic digestion of food waste: Mass, nutrient and energy balance of four digestate liquid treatment systems. J. Clean. Prod. 2016, 125, 22-32. [CrossRef]

27. Muhayodin, F.; Fritze, A.; Rotter, V.S. A Review on the Fate of Nutrients and Enhancement of Energy Recovery from Rice Straw through Anaerobic Digestion. Appl. Sci. 2020, 10, 2047. [CrossRef]

28. Mancini, G.; Papirio, S.; Lens, P.; Esposito, G. A Preliminary Study of the Effect of Bioavailable Fe and Co on the Anaerobic Digestion of Rice Straw. Energies 2019, 12, 577. [CrossRef]

29. Mussoline, W.; Esposito, G.; Lens, P.; Garuti, G.; Giordano, A. Electrical energy production and operational strategies from a farm-scale anaerobic batch reactor loaded with rice straw and piggery wastewater. Renew. Energy 2014, 62, 399-406. [CrossRef]

30. Amon, T.; Amon, B.; Kryvoruchko, V.; Zollitsch, W.; Mayer, K.; Gruber, L. Biogas production from maize and dairy cattle manure-Influence of biomass composition on the methane yield. Agric. Ecosyst. Environ. 2007, 118, 173-182. [CrossRef]

31. Møller, H.B.; Sommer, S.G.; Ahring, B.K. Methane productivity of manure, straw and solid fractions of manure. Biomass Bioenergy 2004, 26, 485-495. [CrossRef]

32. Zhang, H.; Itakura, A.; Matsuto, T. Carbon and nutrient distributions between gas, solid, and liquid in anaerobic digestion facilities for various types of organic waste. Biosyst. Eng. 2012, 113, 11-21. [CrossRef]

33. Gulhane, M.; Khardenavis, A.A.; Karia, S.; Pandit, P.; Kanade, G.S.; Lokhande, S.; Vaidya, A.N.; Purohit, H.J. Biomethanation of vegetable market waste in an anaerobic baffled reactor: Effect of effluent recirculation and carbon mass balance analysis. Bioresour. Technol. 2016, 215, 100-109. [CrossRef]

34. Ma, G.; Neibergs, J.S.; Harrison, J.H.; Whitefield, E.M. Nutrient contributions and biogas potential of co-digestion of feedstocks and dairy manure. Waste Manag. 2017, 64, 88-95. [CrossRef]

35. Wild, D.K., A.; Siegrist, H. Prediction of recycle phosphorus loads from anaerobic digestion. Water Resour. 1997, 31, 2300-2308. [CrossRef]

36. Kataki, S.; Hazarika, S.; Baruah, D.C. Assessment of by-products of bioenergy systems (anaerobic digestion and gasification) as potential crop nutrient. Waste Manag. 2017, 59, 102-117. [CrossRef]

37. Mussoline, W.; Esposito, G.; Lens, P.; Spagni, A.; Giordano, A. Enhanced methane production from rice straw co-digested with anaerobic sludge from pulp and paper mill treatment process. Bioresour. Technol. 2013, 148, 135-143. [CrossRef] [PubMed]

38. Benabdallah El Hadj, T.; Astals, S.; Gali, A.; Mace, S.; Mata-Alvarez, J. Ammonia influence in anaerobic digestion of OFMSW. Water Sci. Technol. 2009, 59, 1153-1158. [CrossRef] [PubMed]

39. Johansen, A.; Carter, M.S.; Jensen, E.S.; Hauggard-Nielsen, H.; Ambus, P. Effects of digestate from anaerobically digested cattle slurry and plant materials on soil microbial community and emission of CO2 and N2O. Appl. Soil. Ecol. 2013, 63, 36-44. [CrossRef]

40. RAL Deutsches Institut für Gütesicherung und Kennzeichnung e. V and Bundesgütegemeinschaft Kompost e. V.; Gütesicherung Kompost RAL: Bonn, Germany, 1992; Volume 251.

41. Barrett, J.E.B.; Burke, I.C. Potential nitrogen immobilization in grassland soils across a soil organic matter gradient. Soil Biol. Biochem. 2000, 32, 1707-1716. [CrossRef]

42. Walsh, J.J.; Jones, D.L.; Edwards-Jones, G.; Williams, A.P. Replacing inorganic fertilizer with anaerobic digestate may maintain agricultural productivity at less environmental cost. J. Plant Nutr. Soil Sci. 2012, 175, 840-845. [CrossRef]

43. Alburquerque, J.A.; de la Fuente, C.; Ferrer-Costa, A.; Carrasco, L.; Cegarra, J.; Abad, M.; Bernal, M.P. Assessment of the fertiliser potential of digestates from farm and agroindustrial residues. Biomass Bioenergy 2012, 40, 181-189. [CrossRef]

44. Lal, R. World cropland soils as a source or sink for atmospheric carbon. Adv. Agron. 2000, 71, 145-191.

45. Rowell, D.M.; Prescott, C.E.; Preston, C.M. Decomposition and Nitrogen Mineralization from Biosolids and Other Organic Materials Relationship with Initial Chemistry. J. Environ. Qual. 2001, 30, 1401-1410. [CrossRef] [PubMed]

46. Tambone, F.; Genevini, P.; Adani, F. The Effects of Short-Term Compost Application on Soil Chemical Properties and on Nutritional Status of Maize Plant. Compos. Sci. Util. 2007, 15, 176-183. [CrossRef]

47. Iakimenko, O.O., E.; Sadovnikova, L.; Persson, J.; Nilsson, I.; Orlov, D.; and Ammosova, Y. Dynamic transformation of sewage sludge and farmyard manure components. 1. Content of humic substances and mineralisation of organic carbon and nitrogen in incubated soils. Agric. Ecosyst. Environ. 1996, 58, 121-126. [CrossRef]

48. Tambone, F.; Scaglia, B.; D’Imporzano, G.; Schievano, A.; Orzi, V.; Salati, S.; Adani, F. Assessing amendment and fertilizing properties of digestates from anaerobic digestion through a comparative study with digested sludge and compost. Chemosphere 2010, 81, 577-583. [CrossRef] [PubMed] 
49. Zilio, M.; Orzi, V.; Chiodini, M.E.; Riva, C.; Acutis, M.; Boccasile, G.; Adani, F. Evaluation of ammonia and odour emissions from animal slurry and digestate storage in the Po Valley (Italy). Waste Manag. 2020, 103, 296-304. [CrossRef]

50. Sahlstrom, L. A review of survival of pathogenic bacteria in organic waste used in biogas plants. Bioresour. Technol. 2003, 87, 161-166. [CrossRef]

51. Owamah, H.I.; Dahunsi, S.O.; Oranusi, U.S.; Alfa, M.I. Fertilizer and sanitary quality of digestate biofertilizer from the co-digestion of food waste and human excreta. Waste Manag. 2014, 34, 747-752. [CrossRef] [PubMed] 